\title{
EFFECT OF FLAXSEED OIL SUPPLEMENTION DURING PRE AND POSTPARTUM ON SOME PHYSIOLOGICAL PARAMETERS AND PRODUCTIVE PERFORMANCE OF FRIESIAN COWS
}

\author{
Y.M. El-Diahy; M.A. Abu El-Hamd and M.A. Elshora \\ Animal Production Research Institute, Agricultural Research Center, Dokki, Egypt
}

(Received 12/1/2016, accepted 29/2/2016)

\section{SUMMARY}

\begin{abstract}
$\mathrm{T}$ The objective of this study was to evaluate the effects of flaxseed oil supplementation into the ration of Friesian cows on their productive, somatic cell count (SCC), physiological and blood parameters during summer season. Twenty four dry pregnant Friesian cows averaged $607 \pm 22.5 \mathrm{~kg}$ live body weight (LBW) at 2-3 parities were randomly assigned into two groups (12 cows in each group). Cows in group $1^{\text {st }}(\mathrm{G} 1)$ did not treatment and served as a control, while those in the $2^{\text {nd }}$ were c received $2 \%$ of DM intake flaxseed oil from 45 days pre-partum until 120 days post-partum. Results revealed that body temperatures degrees of rectal (RT), skin at white (STW) and black (STB) as well as respiration rate (RR) during heat stress period in summer months (June, July, August and September) significantly $(\mathrm{P}<0.05)$ decreased with flaxseed oil as compared to the control group. Flaxseed oil diet improved $(\mathrm{P}<0.05)$ digestibility and rumen activity. Average daily dry matter intake (DMI) and DCP pre-partum were nearly similar for control and flaxseed oil treatment, while the intake of TDN increased significantly $(\mathrm{P}<0.05)$ with flaxseed oil supplementation compared to the control group. Cows of tested treatment On post partum state, DMI and TDN intake were significant higher with oil supplemental ration than the control group, but the difference did not significant between treatments respecting DCPI in this phase. Cows of treatments were higher in red blood cell (RBC) and white blood cell (WBC) counts, hemoglobin ( $\mathrm{Hb}$ ) concentration and haematocrit percentage (HCT, \%) than those of the control group. Cows treatment were higher significantly lymphocytes and significantly lower moncytes than control group. All protein fraction concentrations were higher in treated than in control group (G1). Concentrations of high density lipoprotein and triglyceride were higher significantly $(\mathrm{P}<0.05)$ in $\mathrm{G} 2$ than the control group $(\mathrm{G} 1)$, but, plasma low density lipoprotein concentrations were lower significantly $(\mathrm{P}<0.05)$ in $\mathrm{G} 2$ than the control group $(\mathrm{G} 1)$. Daily milk yield and $4 \%$ fat corrected milk were higher significantly by 19.37 and $29.99 \%$, respectively compared with control. The G2 had higher $(\mathrm{P}<0.05)$ percentages of fat, lactose and total solids as compared to $\mathrm{G} 1$, while protein and solids not fat percentages were similar to G1. Diet supplemented with flaxseed oil showed lower $(\mathrm{P}<0.05)$ somatic cell count in milk as compared to G1. Feed conversion improved $(\mathrm{P}<0.05)$ in G2 than in G1. Economic efficiency was higher with flaxseed oil- ration than that of control one free from oil. It could be concluded that flaxseed oil supplementation in diet of Friesian cows $(2 \% / \mathrm{kg}$ DMI) during pre- and post-partum period heat stress could be eliminated and improved digestibility, productive performance and economic efficiencies as well as immune-response of Friesian cows without adversity effects on haematological and biochemical parameters.
\end{abstract}

Keywords: Friesian cow, feed intake, digestibility coefficients, milk yield and flaxseed oil.

\section{INTRODUCTION}

Transitional period in dairy cows included 3 weeks before and 3 weeks after calving when metabolic processes were adapted to providing energy and precursors required for synthesis of milk compounds (Grummer, 1995, Overton and Waldron, 2004). In consequence in early lactation, such a state caused negative energy balance, a high mobilization of lipids from bodily fat reserves as well as hypoglycaemia (Veenhuizen et al., 1991; Reist et al., 2002).

Flaxseed oil has a very healthy fatty-acid profile, with low levels (approximately 9\%) of saturated fat, moderate levels $(18 \%)$ of monounsaturated fat and high concentrations $(73 \%)$ of polyunsaturated fatty acids (PUFAs). The PUFA content comprises about $16 \%$ omega-6 fatty acids, primarily as linoleic acid (LA), and 57\% alpha linolenic acid (ALA C18:3n-3), an omega-3 fatty acid (DeClercq, 2006). 


\section{El-Diahy et al.}

In early lactation where cows can not consume sufficient dry matter(DM) to support maximal milk yield(NRC, 2001)and as a result the cows are in negative energy balance on the other hand. The transition period is considered to extend from 3-6 week before calving through the first 3-6 week of lactation (Wonnacott et al., 2010). The positive effect of lipid supplementation may be due to specific fatty acids (Staples and Thatcher, 2005), and the absorption of unsaturated FA in ruminants is limited due microbial biohydrogenation in the rumen (Lopes et al., 2009). Some studies have indicated possibility that unsaturated FA intake, particularly those of the n-6 (linoleic acid) and n-3 (linolenic, eicosapentaenoic, docosahexaenoic acids) families, may have some influence on reproduction in cows, even when reports in the literature are not always consistent (Santos et al., 2008).

The concentrations of omega-3 fatty acids in milk are nearly devoid. Therefore, supplementing milk with omega-3 PUFA may provide a more appropriate inflammatory response in septicemic calves (Ballou, 2012; Frei et al., 2012).

However, Vargas et al. (2011) found that flaxseed oil supplemented treatments showed higher propionate and lower butyrate productions compared to the control. As a result, acetate to propionate ratio was notice- ably decreased by oil addition in comparison with control. There were no differences on Llactate concentration. Similar effects on VFA production and molar proportions have been observed by Getachew et al. (2001), Jalc et al. (2006, 2007) and Toral et al. (2009). Zachut et al (2011) reported that dry mater intake from pre-partum not affected, however the postpartum dry mater intake was higher in cows treated flaxseed than control. Also, milk yield was $6.4 \%$ higher in flaxseed than in control, and fat content was 0.4 unit lower in flaxseed cows than in control. Ambrose et al., (2006) reported that higher alfa linolinc acid by $187 \%$ in cows fed flaxseed oil than cows fed sunflower oil $22 \%$, however, linoleic acid increase $122 \%$ in sunflowers than flaxseed oil $74 \%$.

The objective of this study was to evaluate the effects of flaxseed oil of dairy cows on physiological parameters, feed intake, digestibility and blood parameters, as well as milk yield and quality in Friesian cows during transition and early postpartum period of Friesian cows.

\section{MATERIALS AND METHODS}

The present study was carried out at Sakha Animal Production Research Station, belonging to the Animal Production Research Institute, Agricultural Research Center, Ministry of Agriculture and Land Reclamation, Egypt.

\section{Animals and management:}

Twenty four healthy Friesian cows with an average of $607 \pm 22.5 \mathrm{~kg}$ body weight $(\mathrm{BW})$ and $2-3$ parities were chosen at late pre-partum period (45 days pre-partum) to study the effect off supplementation flaxseed oil cows were divided into two similar groups, 12 animal in each. Cows were divided according to their BW, parity and milk production of the previous season. Cows were fed a basal ration consisted of $35 \%$ concentrate feed mixture (CFM), $25 \%$ corn silage (CS) and $40 \%$ rice straw (RS) pre-partum and 55\% CFM, 30\% CS and 15\% RS post-partum without oil supplement in group (G1) and served as control, and supplemented with flaxseed oil at level of $2 \%$ of DM intake in group (G2) from 45 days pre-partum until 120 days post-partum during summer season.

\section{Feeding system:}

Cows were fed a diet containing CFM, rice straw and corn silage according to the recommendation of NRC (2001) for dairy cows based on their live body weight and milk yield. The CFM was composed of $28 \%$ yellow corn grains, 35\% undecorticated cotton seed cake, 32\% wheat bran, 3\% molasses, $1 \%$ limestone and $1 \%$ common salt. Chemical analysis of representative monthly samples of feedstuffs was analyzed for CP, CF, EE, NFE and ash basis according to the official methods of the A.O.A.C. (1995).

\section{Temperature humidity index (THI):}

Daily maximum and minimum values of ambient temperature (AT, $\left.{ }^{\circ} \mathrm{C}\right)$ and relative humidity $(\mathrm{RH} \%$ ) during the entire length of the experimental period are shown in Table (2). The temperature-humidity index (THI) was estimated according to Livestock and Poultry Heat Stress Indices, suggested by Agricultural Engineering Technology Guide, Clemson University, Clemson, Sc. 29634, USA, using the following formula:

$$
T H I=d b^{o} F-(0.55-0.55 R H)(d b-58)
$$


Where:

$\mathrm{db}{ }^{\circ} \mathrm{F}=$ dry bulb temperature in Fahrenheit.

$\mathrm{RH}=$ relative humidity $(\mathrm{RH} / 100)$.

The obtained values of THI were classified as follows:

Less than $72=$ absence of heat stress.

72 to $74=$ moderate heat stress.

74 to $<76=$ severe heat stress.

Over $76=$ very severe heat stress.

\section{Body temperatures and respiration rate:}

Throughout the experimental period from July up to October, body temperatures including rectal (RT) as well as skin temperatures at white (STW) and black (STB) sites were recorded twice weekly at 13;00 h using digital precision thermometer (TRD, Ellab Cropcopen Hagen, Denmark). At the same time, respiration rate (RR) was measured by counting the flank movements for one minute using stop watch.

\section{Digestion trials:}

Two digestibility trails were conducted pre and post-partum to determined digestibility coefficients (\%) of various nutrients of the experimental rations using acid insoluble ash as a marker (Van Kulin and Young, 1977). Nutritive values (\%) in terms of TDN and DCP of different experimental rations were calculated according to the obtained digestibility coefficients. Representative samples from CFM, CS, $\mathrm{RS}$, and feces were also taken and prepared for the chemical analysis by the methods of A.O.A.C. (1995).

\section{Rumen Liquor sampling:}

Post-partum rumen liquor samples were taken from three cows randomly chosen from each group using stomach tube at four hours post feeding. The ruminal fluid was strained through double layers of cheese cloth and $\mathrm{pH}$ values determind were immediately determined using digital $\mathrm{pH}$-meter (Model HI 8424). Two $\mathrm{ml}$ toluene and $2 \mathrm{ml}$ paraffin oil were added to each rumen liquor sample and then stored at $20{ }^{\circ} \mathrm{C}$ until determination the concentration of ammonia-nitrogen and volatile fatty acids. Ammonianitrogen $\left(\mathrm{NH}_{3}-\mathrm{N}\right)$ concentration was determined according to micro diffusion method (Conway, 1978), while concentration of total volatile fatty acids (VFA's) was determined by distillation according to Eadie et al. (1967).

\section{Blood sampling:}

During the experimental period, blood samples were biweekly collected in clean test tubes via jugular vein from all cows in each group. Blood plasma was separated by centrifugation at $4000 \mathrm{rpm}$ for $10 \mathrm{~min}$, and then plasma was kept frozen at $-20{ }^{\circ} \mathrm{C}$ until chemical analyses. Hematological parameters including count of red blood cells (RBCs), white blood cells (WBCs), haematocrit (\%), and hemoglobin concentration were counted or measured in fresh whole blood using fully digital haematology counter (Laboratories, USA). Concentration of total proteins (Gornall et al., 1949) and albumin (Wichselarm, 1946) in blood plasma were determined using commercial kits (Diagnostic System Laboratories, Inc USA). Plasma globulin was calculated by subtracting concentration of albumin from total proteins.

\section{Milk yield and milk composition:}

Cows were machine milked twice daily at 6:00 and 17:00 h. Daily milk yield (morning and evening) was individually recorded for the 120 days of lactation Season. Milk samples were bimonthly collected to determine milk composition using Milko-Scan (Model 133B). The 4\% fat corrected milk (4\% FCM) for each cow was calculated from milk yield according to the following formula:

$4 \% \mathrm{FCM}=$ actual milk yield $(\mathrm{kg}) \times 0.4+15$ x fat yield $(\mathrm{kg})$ Geans equation, (cited by Abou-Raya, 1967).

\section{Somatic cell count $(\mathrm{SCC})$ :}

After bacteriological plating, SCC were determined for each milk sample with a Fossomatic 90 (A/S $\mathrm{N}$ Foss Electric, Hillerod, Denmark) between 24 and $48 \mathrm{~h}$ post collection using the previously described method by (Gonzalo et al., 1993).

\section{Feed conversion ratio:}

Feed conversion ratio expressed as the amounts of DM, TDN and DCP required per one $\mathrm{kg} 4 \% \mathrm{FCM}$ yield were calculated for each cow. 


\section{Economic efficiency:}

Average daily feed cost, feed cost per one $\mathrm{kg} \mathrm{FCM}$ and the price of daily $4 \%$ FCM yield were calculated for each cow. Also, economic efficiency expressed as the ratio between the price of daily $4 \%$ FCM yield and average daily feed cost were calculated.

\section{Statistical analysis:}

Data were statistically analyzed using SAS (2004). The significant differences among treatment groups were tested using $\mathrm{T}$ test.

\section{RESULTS AND DISCUSSION}

\section{Temperature humidity index:}

Data in Table (1) revealed that cows in all groups were exposed to heat stress during the experimental period, being moderate $(\mathrm{THI}=72-74)$ during June and July and very sever (THI over 76) during August and September.

Table (1): Average values of ambient temperature $\left({ }^{\circ} \mathrm{C}\right)$ and relative humidity (RH\%) during summer months of the experimental period.

\begin{tabular}{|c|c|c|c|c|}
\hline \multirow{2}{*}{ Item } & \multicolumn{4}{|c|}{ Experimental period during: } \\
\hline & June & July & August & September \\
\hline \multicolumn{5}{|c|}{ Ambient temperature (oC): } \\
\hline Maximum & $32.9 \pm 2.2$ & $32.2 \pm 1.3$ & $34.8 \pm 1.4$ & 32.7 \\
\hline Minimum. & $19.1 \pm 1.3$ & $17.0 \pm 2.3$ & $19.6 \pm 2.4$ & 22.78 \\
\hline \multicolumn{5}{|c|}{ Relative humidity (RH\%): } \\
\hline Maximum & $89.5 \pm 12.4$ & $90.5 \pm 6.5$ & $93.0 \pm 8.4$ & 91.16 \\
\hline Minimum. & $53.0 \pm 8.5$ & $60.4 \pm 7.4$ & $58.0 \pm 6.4$ & 66.35 \\
\hline \multicolumn{5}{|c|}{ Temperature humidity index (THI): } \\
\hline THI & $72.05 \pm 9.5$ & $73.23 \pm 7.4$ & $79.81 \pm 4.6$ & 80.40 \\
\hline
\end{tabular}

\section{Thermoregulatory responses:}

Data in Table (2) show that body temperatures including RT, WST and BST as well as RR during heat stress period in summer months (June, July, August and September) significantly $(\mathrm{P}<0.05)$ lower with flaxseed oil as compared to the control group.

It is of interest to note that the observed increase in THI values in August and September reflected in tendency of higher response of cows in control and treated groups in term of higher RT, WST, BST and RR than in June and July .

Similar trends of changes in body temperatures were reported on Friesian calves (Fawzy et al., 1998 and Abu El-Hamd, 2000) and on Friesian bulls (Fawzy and Rabie, 1996 and Abdel-Khalek, 2000). Generally, exposing cows to heat stress during summer months caused disturbances in animal body thermoregulation, resulting in marked increase $(\mathrm{P}<0.05)$ in RT and RR (Abdel-Samee, 1995 \& 1997) and Marai et al. (1997). The observed trend of decrease in WST and BST in treatment groups than in the control group was similar to that obtained by Salem et al. (1984) in cattle and Abu El-Hamd (2000) in Friesian calves.

It is worthy noting that treatment resulted in significantly $(\mathrm{P}<0.05)$ lower $\mathrm{RT}$ rather than those observed in WST, BST and RR (Table 2). This may be a strong reaction of control cows to store heat in their bodies more than treated cows (Abdel-Samee, 1998). 
The relatively low RR in flaxseed oil treated cows may be due to higher respiration efficiency in treated cows by increasing the depth of air changing rather than increasing their number (Kobeisy, 1994 and Yousef et al., 1997) and in Friesian calves (Abu El-Hamd, 2000).

Generally, physiological response in terms of RT, WST, BST and RR in June, July and August (Table 2) was in relation to THI values during summer season (Table 1). In cows exposed to heat stress, respiratory rate decreased and both peripheral blood flow and sweating increased. These responses have a deleterious effect on physiologic status of the cow (West, 2003).

Table (2): Rectal and skin temperatures and respiration rate during postpartum of Friesian cows treated with different levels of flaxseed oil.

\begin{tabular}{|c|c|c|c|}
\hline Item & Control (G1) & Treatment group (G2) & Sign. \\
\hline \multicolumn{4}{|c|}{ Rectal temperature (oC): } \\
\hline June & $40.33 \pm 0.20$ & $39.10 \pm 0.20$ & ** \\
\hline July & $39.92 \pm 0.08$ & $39.19 \pm 0.10$ & $*$ \\
\hline August & $40.51 \pm 0.20$ & $39.43 \pm 0.10$ & $*$ \\
\hline September & $39.97 \pm 0.10$ & $39.28 \pm 0.10$ & $*$ \\
\hline \multicolumn{4}{|c|}{ Skin temperature (oC) for white site: } \\
\hline June & $34.79 \pm 0.1$ & $33.28 \pm 0.20$ & $*$ \\
\hline July & $34.28 \pm 0.12$ & $33.68 \pm 0.13$ & $*$ \\
\hline August & $35.18 \pm 0.2$ & $34.08 \pm 0.20$ & $*$ \\
\hline September & $35.06 \pm 0.2$ & $34.08 \pm 0.20$ & $*$ \\
\hline \multicolumn{4}{|c|}{ Skin temperature (oC) for black site: } \\
\hline June & $34.69 \pm 0.14$ & $33.69 \pm 0.12$ & $*$ \\
\hline July & $35.07 \pm 0.21$ & $33.97 \pm 0.23$ & $*$ \\
\hline August & $36.22 \pm 0.20$ & $35.67 \pm 0.17$ & $*$ \\
\hline September & $36.10 \pm 0.12$ & $35.37 \pm 0.17$ & $*$ \\
\hline \multicolumn{4}{|c|}{ Respiration rate (times/min) } \\
\hline June & $66.72 \pm 4.1$ & $52.17 \pm 3.5$ & $* *$ \\
\hline July & $58.33 \pm 3.4$ & $48.25 \pm 3.1$ & $* *$ \\
\hline August & $67.33 \pm 4.2$ & $53.17 \pm 3.6$ & $* *$ \\
\hline September & $65.20 \pm 4.1$ & $50.42 \pm 3.8$ & $* *$ \\
\hline
\end{tabular}

* Significantly at $P<0.05$ and $* *$ significantly at $P<0.01$.

\section{Chemical composition of rations and its ingredients:}

Chemical composition of ingredients and experimental ration are presented in Table (3). Chemical composition of experimental rations revealed marked increase in EE content by 92.89 and $78.95 \%$ and NFE content decreased by 2.0 and $1.99 \%$ with flaxseed oil supplementation pre and post-partum; respectively. While, OM content tended to increase and the contents of $\mathrm{CP}, \mathrm{CF}$ and ash tended to decreased with linseed oil supplementation. Chemical composition of rice straw and corn silage used in this study are commonly comparable to those recorded in the literature.

Table (3): Chemical composition of ingredients and experimental rations during the pre-and post partum periods.

\begin{tabular}{lccccccc}
\hline \multirow{2}{*}{ Item } & \multicolumn{7}{c}{ Composition of DM \% } \\
\cline { 2 - 7 } & DM \% & OM & CP & CF & EE & NFE & Ash \\
\hline Ingredients & & & & & & & \\
CFM & 89.71 & 91.58 & 15.62 & 9.63 & 2.92 & 63.41 & 8.42 \\
Corn silage & 35.10 & 94.89 & 7.39 & 24.18 & 2.19 & 61.13 & 5.11 \\
Rice straw & 91.08 & 83.58 & 2.98 & 34.89 & 1.36 & 44.35 & 16.42 \\
Experimental rations & & & & & & & \\
Pre-partum & & & & & & & 10.79 \\
Control & 64.90 & 89.21 & 8.51 & 23.37 & 2.11 & 55.22 & 10.57 \\
Treatment & 64.85 & 89.43 & 8.34 & 22.90 & 4.07 & 54.12 & \\
Post-partum & & & & & & & \\
Control & 61.25 & 91.37 & 11.26 & 17.78 & 2.47 & 59.86 & 8.63 \\
Treatment & 60.51 & 91.54 & 11.03 & 17.42 & 4.42 & 58.67 & 8.46 \\
\hline
\end{tabular}




\section{El-Diahy et al.}

\section{Digestibility coefficients and nutritive values.}

Results of nutrient digestibility coefficients and nutritive values of experimental rations by Friesian cows are shown in Table (4). The digestibility coefficients and nutritive values pre and post-partum increased significantly $(\mathrm{P}<0.05)$ with flaxseed oil supplementation except $\mathrm{CP}$ digestibility and DCP value post-partum. Flaxseed oil supplementation showed significantly increased in TDN value of the experimental rations by 6.55 and $6.84 \%$ pre and post-partum, respectively. The increase of TDN value with flaxseed oil supplementation might be attributed to the increase of EE content, which increased by 92.89 and $78.95 \%$ pre- and post-partum (Table 3). The results agreement with, Abu El-Hamd et al. (2015) who found that digestibility coefficients and nutritive values were significantly improved with flaxseed oil supplementation in Friesian calves as compared to the control group and Khattab et al. (2011), when buffalo calves were fed on black seed oil.

These results cleared that protected fat and oil supplementation in the experimental ration in dairy cows improved the digestibility and nutritive values in this respect, Chouinard et al.(1998), found that the addition of protected fat in ration of Holstein dairy cows improved nutrients digestibilities and nutritive values, which confirm the present results. Also, Andrew et al (1991) reported that digestibility and metabolizable energy were higher for ration supplemented with protected fat. However, (El-Diahy, 2004) found that addition of protected fat and oil in ration of dairy cows improved nutrients digestibilities and nutritive values.

Finally, similar effects in respect of digestibility of most nutrients and feeding value were also found by (Bendary et al, 1994 ) with fattening buffalo calves and (Mostafa et al, 1995) with lactating buffaloes using $5 \%$ or $7.5 \%$ of total ration of palm oil supplemented.

Table (4): Digestibility coefficients and nutritive values of experimental rations during the pre-and post- partum periods

\begin{tabular}{lcccccccc}
\hline \multirow{2}{*}{ Item } & \multicolumn{3}{c}{ Pre-partum } & \multicolumn{5}{c}{ Post-Partum } \\
\cline { 2 - 9 } & Control & Treatment & MSE & Sign. & Control & Treatment & MSE & Sign. \\
\hline Digestibility coefficients $\%$ & & & & & & & & $*$ \\
DM & 61.46 & 63.24 & 0.33 & $*$ & 65.52 & 67.43 & 0.38 & $*$ \\
OM & 64.55 & 66.45 & 0.41 & $*$ & 68.54 & 70.43 & 0.42 & NS \\
CP & 58.53 & 63.26 & 1.13 & $*$ & 68.99 & 70.67 & 0.62 & $*$ \\
CF & 61.85 & 65.76 & 1.07 & $*$ & 66.17 & 70.35 & 1.11 & $*$ \\
EE & 72.73 & 76.38 & 0.93 & $*$ & 80.78 & 87.24 & 1.53 & NS \\
NFE & 66.63 & 67.00 & 0.36 & NS & 68.99 & 69.95 & 0.52 & \\
Nutritive values $\%$ & & & & & & & & \\
TDN & 59.68 & 63.59 & 1.38 & $*$ & 65.30 & 69.77 & 1.06 & $*$ \\
DCP & 4.98 & 5.28 & 0.06 & $*$ & 7.77 & 7.79 & 0.05 & NS \\
\hline
\end{tabular}

\section{Daily feed intake:}

Average daily feed intake by Friesian cows pre- and post-partum are presented in Table (5). Total DM and DCP intake pre-partum were nearly similar for control and flaxseed oil treatment, while the intake of TDN increased significantly $(\mathrm{P}<0.05)$ with flaxseed oil supplementation. Also, the total DM and TDN intake post-partum increased significantly $(\mathrm{P}<0.05)$ with flaxseed oil supplementation, but DCP intake was nearly similar for the two groups. Feed intake reflect the variation in TDN and DCP values presented in Table (4). The results are in agreement with those observed by Zachut et al (2011) who reported that dry mater intake from pre-partum not affected, however the postpartum dry mater intake was higher in cows with treated flaxseed oil than control. Also, milk yield was $6.4 \%$ higher in flaxseed than in control, and fat content was 0.4 unit lower in flaxseed cows than in control. Drouillard et al. (2002) fed flaxseed oil at $0,5,10$ and 15 percent of diet DM of cattle and found that when fed at 5 percent increased DM intake. Ambrose et al., (2006) reported that higher alfalinolinc acid by $187 \%$ in cows fed flaxseed oil than cows fed sunflower oil 22\%, however, linoleic acid increase $122 \%$ in sunflowers than flaxseed oil $74 \%$. Maddock et al. (2004) fed whole or processed (rolled or ground) flax, included at 8 percent of diet DM, and reported significant increases in gain and gain efficiency. 
Vargas et al. (2011) found that flaxseed oil supplementation were higher OM, CP and NDF disappearance than Sunflower oil treatment, with intermediate values in control and olive oil treatments and no differences between treatments in medium $\mathrm{pH}$, total VFA and acetate production. Although, feeding lipids can inhibit fiber digestion in the rumen (Jenkins, 1993). On the other hand, Jalc et al. (2007), showed did not differences in DM or NDF degradation when the diet was supplemented with oleic, linoleic or linolenic acids.

Table (5): Average daily feed intake (kg/head) during pre-and post- partum periods by cows fed experimental rations

\begin{tabular}{|c|c|c|c|c|c|c|c|c|}
\hline \multirow{2}{*}{ Item } & \multicolumn{4}{|c|}{ Pre-partum } & \multicolumn{4}{|c|}{ Post-Partum } \\
\hline & Control & Treatment & MSE & Sig & Control & Treatment & MSE & Sig \\
\hline CFM $(\mathrm{kg})^{1}$ & 5.58 & 5.66 & & & 10.43 & 10.73 & & \\
\hline Corn silage $(\mathrm{kg})^{1}$ & 10.19 & 10.33 & & & 14.54 & 14.96 & & \\
\hline Rice straw $(\mathrm{kg})^{1}$ & 6.28 & 6.37 & & & 2.80 & 2.88 & & \\
\hline $\operatorname{Oil}(\mathrm{g})^{1}$ & 00 & 290 & & & 00 & 350 & & \\
\hline Total DM (kg) & 14.31 & 14.79 & 0.20 & NS & 17.01 & 17.85 & 0.21 & $*$ \\
\hline TDN $(\mathrm{kg})$ & 8.54 & 9.40 & 0.16 & $*$ & 11.11 & 12.45 & 0.18 & $* *$ \\
\hline DCP (kg) & 0.713 & 0.781 & 0.04 & NS & 1.32 & 1.39 & 0.05 & NS \\
\hline
\end{tabular}

${ }^{I}$ Fresh basis, NS: not significant *Significantly at 0.05, ** Significantly at 0.01 .

\section{Rumen parameters:}

Post-partum rumen parameters in Table (6) showed that $\mathrm{pH}$ values was not significant affected by flaxseed oil supplementation. While, total VFA concentration increased, but $\mathrm{NH}_{3}-\mathrm{N}$ concentration decreased significantly $(\mathrm{P}<0.05)$ with flaxseed oil supplementation. These results illustrated that flaxseed oil supplementation stimulate the growth of rumen microorganisms utilizing ruminal $\mathrm{NH}_{3}-\mathrm{N}$ and fermented the carbohydrates producing VFA. These results confirmed with increasing CF digestibility with linseed oil supplementation (Table 5). The results agreement with, Chen and Russell (1989) affirmed that the reduction of $\mathrm{NH}_{3}-\mathrm{N}$ concentration may be related to the depression effect of unsaturated lipids on the population of gram positive bacteria, notably the amino acid-fermenting mandatory group, to supply their energy and protein requirements.

Table (6): Some rumen fermentation activity of cows fed experimental rations post-partum.

\begin{tabular}{|c|c|c|c|c|}
\hline \multirow[t]{2}{*}{ Item } & \multicolumn{3}{|c|}{ Experimental groups $(\mathrm{n}=12)$} & \multirow[t]{2}{*}{ Sign. } \\
\hline & Control & Treatment & MSE & \\
\hline PH value & 6.31 & 6.26 & 0.02 & NS \\
\hline TVFA's (meq/100ml) & 9.48 & 11.33 & 0.41 & $*$ \\
\hline $\mathrm{NH}_{3}-\mathrm{N}(\mathrm{mg} / 100 \mathrm{ml})$ & 18.45 & 16.30 & 0.52 & $*$ \\
\hline
\end{tabular}

NS: Not significant, *Significantly at 0.05, ** Significantly at 0.01 .

\section{Haematological parameters and immune response:}

Data in Table $(7)$ showed that significant $(\mathrm{P}<0.05)$ improvement of red blood cell $(\mathrm{RBC})$ and white blood cell (WBC) counts, hemoglobin $(\mathrm{Hb})$ concentration and haematocrit percentage (HCT, \%) of cows fed flaxseed oil supplemented diets.

Flaxseed oil supplementation significantly $(\mathrm{P}<0.05)$ improved immune response of treated cows. Treated cows showed significantly higher lymphocytes in control and significantly $(\mathrm{P}<0.05)$ reduced monocytes as compared to control group. Alfa-linolinc acid is an essential flaxseed oil which plays an important role in immune response of the animal. The supply of flaxseed oil improves performance, health, and immune function (Abu El-Hamd et al., 2015). Research indicates several possible human health benefits associated with consumption of flaxseed oil (Conners, 2000). Flaxseed oil contains approximately 20 percent alpha linolenic acid (ALA; DM basis), an essential omega-3 fatty acid that is a precursor for eicosapentaenoic acid (EPA), which in turn is a precursor for the formation of eicosanoids. 
Eicosanoids are hormone-like compounds that play an essential role in immune response. These results might be optimize resistance to diseases by enhancing the lymphocytes population (Ndiweni and Finch,1995). These changes in deferential leucocytes count may refer to positive improvement of the immune response in the body.

Table (7). Haematological parameters and immune response as affected by flaxseed oil supplementation, throughout the first 120 days of lactation

\begin{tabular}{|c|c|c|c|c|}
\hline \multirow{2}{*}{ Item } & \multicolumn{3}{|c|}{ Experimental groups } & \multirow{2}{*}{ Sign. } \\
\hline & Control & Treatment & $\pm \mathrm{MSE}$ & \\
\hline \multicolumn{5}{|l|}{ Haematological parameters: } \\
\hline$\left(10^{3} / \mathrm{mm}^{3}\right)$ & 10.12 & 12.25 & 0.52 & $*$ \\
\hline$(\mathrm{g} / \mathrm{dL})$ & 9.62 & 10.83 & 0.21 & $*$ \\
\hline$\left(10^{6} / \mathrm{mm}^{3}\right)$ & 6.58 & 7.62 & 0.23 & $*$ \\
\hline Haematocrit (HCT, \%) & 27.6 & 30.52 & 0.65 & $*$ \\
\hline \multicolumn{5}{|l|}{ Immune response: } \\
\hline Lymphocytes (\%) & 63.56 & 69.62 & 1.95 & $*$ \\
\hline Monocytes $\quad(\%)$ & 13.68 & 10.46 & 1.05 & $*$ \\
\hline Granulocytes (\%) & 22.31 & 19.60 & 1.24 & NS \\
\hline
\end{tabular}

NS: not significant, *Significantly at 0.05 , ** Significantly at 0.01 .

\section{Biochemical parameters in blood:}

Data in Table (8) shown concentrations of total protein, albumin and globulin of cows blood serum were significantly $(\mathrm{P}<0.05)$ higher of adding flaxseed oil the ration as compared to the control group during pre or post-partum. Flaxseed oil is essential polyunsaturated fatty acids that is a constituent of enzymes involved in most metabolic pathways, and is important for protein metabolism, cell growth and repair, and immune function. The long-term effects of mild deficiency are unclear, but it has been suggest that they include delayed wound healing, suboptimal immune functioning, increased plasma lipid peroxides and perhaps reduced taste and smell acuity seen in the elderly (Fortes et al. 1997). The present values of serum total protein are within the normal range and in good agreement with those obtained by several investigators (Lee et al., 2008; Abu El-Hamd et al., 2015) on calves. Also, data revealed that concentration of TCH and LDL were significant declined with flaxseed oil ration compared with these of control ration. Inversely trend between treatments was occurred in respect of HDL and triglyceride items these results are similar to those reported by Bianchi et al. .(2014) who stated that triglycerides levels had significant increased in dairy sheep fed 4 or $6 \%$ palm oil- ration in comparison with the oil free one.

Table (8). Concentration of biochemical parameters in serum as affected by flaxseed oil supplementation, throughout the first 120 days of lactation

\begin{tabular}{lcccc}
\hline \multirow{2}{*}{ Item } & \multicolumn{3}{c}{ Experimental group } & \multirow{2}{*}{ Sign. } \\
\cline { 2 - 4 } & Control & Treatment & \pm MSE & $*$ \\
\hline Total protein $(\mathrm{g} / 100 \mathrm{ml})$ & 7.46 & 7.74 & 0.03 & $*$ \\
Albumin $\quad(\mathrm{g} / 100 \mathrm{ml})$ & 3.92 & 4.20 & 0.02 & $*$ \\
Globulin $\quad(\mathrm{g} / 100 \mathrm{ml})$ & 3.25 & 3.67 & 0.01 & $*$ \\
Total cholesterol $(\mathrm{TCH}, \mathrm{mg} / \mathrm{dL})$ & 170.4 & 161.2 & 3.12 & $* *$ \\
High density lipoprotein $(\mathrm{HDL}, \mathrm{mg} / \mathrm{dL})$ & 67.19 & 90.15 & 3.80 & $* *$ \\
Triglyceride $(\mathrm{mg} / \mathrm{dL})$ & 27.35 & 40.00 & 0.85 & $* *$ \\
Low density lipoprotein $(\mathrm{LDL}, \mathrm{mg} / \mathrm{dL})$ & 97.18 & 63.05 & 4.62 & $* *$ \\
\hline
\end{tabular}

NS: not significant, *Significantly at 0.05, ** Significantly at 0.01, *** Significantly at 0.001, 
Flaxseed contains a high oil level (40\% of total seed weight) with a-linolenic acid constituting approximately 55\% of oil's total fatty acids (Mustafa et al., 2002; Petit, 2003). Moreover, diets rich in omega-3 fatty acids (including a-linolenic acid) reduce platelet aggregation, blood triglycerides and cholesterol levels and the occurrence of blood clots, and show both antithrombotic and anti-inflammatory effects (Nash et al., 1995; Simopoulos, 1996). Also, Abu El-Hamd et al. (2015) found that flaxseed oil reduced total lipids concentration in blood on calves.

\section{Milk yield and composition:}

Results in Table (9) showed that daily actual milk yield and 4\% fat corrected milk yield were significantly higher $(\mathrm{P}<0.05)$ with flaxseed oil the ration than those of control group. Also, flaxseed oil during pre- and post-partum periods improved fat and total solids percentages as compared to the control, but protein, lactose and solids percentages not fat were not significant. This may indicate that flaxseed oil during pre- and post-partum has a positive reflection on the yield of fat and protein (Table 9). On the other hand, flaxseed oil reduced $(\mathrm{P}<0.05)$ somatic cell count in milk of treated group as compared to the control.

Interesting, cows treated with flaxseed oil diet improved $(\mathrm{P}<0.05)$ daily milk production and $4 \%$ fat corrected milk of 19.37 and $29.99 \%$, respectively compared with control. The present results come in line with the findings of the higher milk yields were published in some studies (Petit et al., 2001; 2004). Moallem (2009) reported that the average daily milk production was $1.2 \mathrm{~kg}(2.7 \%)$ higher in the dairy cows supplemented with extruded linseed at $40 \mathrm{~g} / \mathrm{kg}$ DM compared to the control diet. Zachut et al. (2011) who found that milk yield was $6.4 \%$ higher in flaxseed than in control, and fat content was 0.4 unit lower in flaxseed cows than in control. Ambrose et al. (2006) reported that higher alfalinolinc acid by $187 \%$ in cows fed flaxseed oil than cows fed control. Moreover, Martin et al. (2008) found that milk yields of dairy cows supplemented with linseed oil was decreased while there was no negative effect on dairy cows supplemented with crude linseed or extruded linseed.

Table (9). Yield and composition of milk and somatic cell count as affected by flaxseed oil supplementation, throughout the first 120 days of lactation

\begin{tabular}{|c|c|c|c|c|}
\hline \multirow{2}{*}{ Item } & \multicolumn{2}{|c|}{ Experimental group } & \multirow{2}{*}{$\pm \mathrm{MSE}$} & \multirow{2}{*}{ Sign } \\
\hline & Control & Treatment & & \\
\hline \multicolumn{5}{|c|}{ Average daily milk yield (kg/day): } \\
\hline Actual milk yield & 15.38 & 18.36 & 0.8 & $* *$ \\
\hline $4 \%$ fat corrected milk & 13.91 & 18.08 & 0.7 & $* * *$ \\
\hline \multicolumn{5}{|l|}{ Milk composition (\%): } \\
\hline Total solids & 10.45 & 11.13 & 0.65 & $*$ \\
\hline Fat & 3.36 & 3.90 & 0.10 & $* *$ \\
\hline Protein & 2.45 & 2.49 & 0.08 & NS \\
\hline Lactose & 4.04 & 4.04 & 0.09 & NS \\
\hline Solids not fat & 7.09 & 7.23 & 0.87 & NS \\
\hline Somatic cell count $\left(10^{3} / \mathrm{ml}\right)$ : & 345.5 & 264.6 & 12.95 & $*$ \\
\hline
\end{tabular}

NS: not significant, *Significantly at 0.05, ** Significantly at 0.01.

Somatic cell count was decreased in cows treated with flaxseed oil diet than control group, being of $40.1 \%$ compared with control. These results are similar to those obtained by Strusinska et al. (2006), who reported that somatic cell count decreased during the first 120 days of lactation by Megapro Plus ${ }^{\circledR}$ supplementation to diet. Also, Abu El-Hamd et al. (2012) found that the SCC was lower $(\mathrm{P}<0.01)$ by about $19.52 \%$ for cows fed protected fat than the control. Research has shown several health benefits of omega-3 fatty acids (including $\alpha$-linolenic acid) to humans including a decrease in the incidence of cancer, cardiovascular diseases, hypertension, and arthritis and an improvement in visual ability (Simopoulos, 1996; Wright et al., 1998). 


\section{El-Diahy et al.}

It is worthy noting in this study that the significant $(\mathrm{P}<0.05)$ increase in milk production parameters of cows in treated group was mainly associated with marked reduction $(\mathrm{P}<0.05)$ in estimated body temperatures and RR of cows in this group as compared to the control group. Fuquay (1981) reported that lactating dairy cows are susceptible to heat stress during summer because of elevated internal heat production associated with lactation. During periods of heat stress, milk production, feed intake, and physical activity decreased. West $e t$ al. (2003) found that changes in cow body temperature (measured as milk temperature) were most sensitive to same day climatic factors. Cow DM intake and milk yield were most affected by climatic variables, not cow body temperature. Holter et al. (1997) reported heat stress decreased intake of cows more than heifers. In lactating dairy cows DMI begins to decline at mean daily environmental temperatures of 25 to $27^{\circ} \mathrm{C}$ and the environmental temperature at which feed consumption begins to decline is influenced by diet composition, for example, the greater proportion of roughage in the diet, the greater and the more rapid in the DMI as environmental temperature rise (Beede and Collier, 1986). Additionally, increased respiratory rates and water intake in heat stressed cows lead to concomitant reductions in DMI (Mallonée et al., 1985). Attebery and Johnson (1969) measured the effect of temperature on rumen motility when feed intake was maintained at a constant level and determined if changes in rumen motility are influenced directly by environmental temperature rather than indirectly by changes in feed consumption resulting from differences in environmental temperature. Igono et al. (1992) investigated the effect of environmental temperature on milk production of Holstein cows in a desert climate and found that milk production declined markedly with maximum THI greater than 76, minimum THI greater than 64 , or mean THI greater than 72. In the literature, West (2003) showed that milk yield and DMI exhibited significant declines when maximum THI reach 77. Estimated milk yield reduction was $0.32 \mathrm{~kg}$ per unit increase in THI (Ingraham, et al., 1979) and milk yield and TDN intake declined by 1.8 and $1.4 \mathrm{~kg}$ for each $0.55^{\circ} \mathrm{C}$ increase in rectal temperature (West, 2003). Ravagnolo et al. (2000) estimated the effect of heat stress on milk production using THI and reported that milk yield declined by $0.2 \mathrm{~kg}$ per unit increase in THI when THI exceeded 72 and the authors suggested that THI can be used to estimate the effect of heat stress on production.

\section{Feed conversion ratio and economic efficiency:}

Feed conversion ratio as affected by flaxseed oil supplementation are shown in Table (10). Flaxseed oil supplementation improved feed conversion ratio, which significantly $(\mathrm{P}<0.05)$ decreased the amounts of DM, TDN and DCP required for produce one $\mathrm{kg} \mathrm{4 \%} \mathrm{FCM} \mathrm{in} \mathrm{compared} \mathrm{to} \mathrm{control} \mathrm{group.} \mathrm{These} \mathrm{results}$ agreed with those obtained by Abu El-Hamd et al. (2015) who found that feed conversion were significantly improved with flaxseed oil supplementation in Friesian calves as compared to the control group and Khattab et al. (2011), who found that feed conversion values of buffalo calves were significantly better for groups supplemented by black seed oil than the other groups.

Table (10). Feed conversion ratio and economic efficiency as affected by flaxseed oil supplementation.

\begin{tabular}{|c|c|c|c|c|}
\hline \multirow{2}{*}{ Item } & \multicolumn{2}{|c|}{ Experimental group } & \multirow{2}{*}{ MSE } & \multirow{2}{*}{ Sign. } \\
\hline & G1 & $\mathrm{G} 2$ & & \\
\hline \multicolumn{5}{|l|}{ Feed conversion ratio: } \\
\hline DM (kg/kg 4\% FCM) & 1.22 & 0.99 & 0.03 & $*$ \\
\hline TDN (kg/kg 4\% FCM) & 0.80 & 0.69 & 0.02 & $*$ \\
\hline $\mathrm{DCP}(\mathrm{g} / \mathrm{kg} 4 \% \mathrm{FCM})$ & 94.90 & 76.88 & 4.2 & $* *$ \\
\hline \multicolumn{5}{|l|}{ Economic efficiency: } \\
\hline Average daily feed cost (LE) & 28.18 & 34.59 & & $*$ \\
\hline Feed cost (LE/kg 4\% FCM) & 2.03 & 1.93 & & NS \\
\hline Price of $4 \%$ FCM yield (LE) & 44.80 & 60.27 & & $*$ \\
\hline Net revenue (LE) & 16.62 & 25.32 & & $*$ \\
\hline Net revenue improvement $\%$ & 100.00 & 152.35 & & $* *$ \\
\hline
\end{tabular}

The prices of one ton were 2250 LE for concentrate feed mixture (CFM), 280 LE for corn silage and 230 LE for rice straw. While, the price of one $\mathrm{kg}$ was $16 \mathrm{LE}$ for flaxseed oil and $2.5 \mathrm{LE}$ for milk according to the prices of 2015. 
Results of economic efficiency in Table (10) showed that average daily feed cost, price of $4 \%$ FCM yield, net revenue and net revenue improvement were significantly $(\mathrm{P}<0.05)$ higher for flaxseed oil supplemented group in than those of control group.

Net revenue increased by $52.35 \%$ for G2 compared to (G1). However, feed cost per one kg $4 \%$ FCM was the same for the two groups and not affected by flaxseed oil supplementation. These results agreed with those obtained by Abu El-Hamd et al. (2015) who found that economic efficiency was improved with flaxseed oil supplementation in Friesian calves as compared to the control group and Mohsen et al. (2011), by using whole sunflower seeds supplementation in goats.

In perspective, however, emphasizably fat inclusion in diet being permit overall higher productive performance of animals, it could be considered as cheap energy source permitting an increase of dietary energy content for a moderate cost which keeping sufficient dietary fiber (roughage) level in the diets. Further research must be performed to ascertain the possible benefits of different sources and level of oil and fat supplementation into the rations of ruminant animals, in terms of body development, grows milk / meat production, immune response and resistance to diseases.

\section{CONCLUSION}

The current study concluded that heat stress could be eliminated, improved digestibility coefficients and nutritive values, milk production and composition and decreased somatic cell count $\left(10^{3} / \mathrm{ml}\right)$, as well as improved economic efficiencies and immune response of treated cows by receiving $2 \% / \mathrm{kg}$ diet.

\section{REFERENCES}

A.O.A.C. (1995). Official Methods of Analysis, Association of Official Chemists, Washington, USA.

Abdel-Khalek, A.E. (2000). Thermoregulatory, haematological and metabolic responses of solar-radiated Friesian bulls fed dietary protected fat. J. Agric. Sci., Mansoura Univ. 25(8): 4967-4977.

Abdel-Samee, A.M. (1995). Using some antibiotics and probiotics for alleviating heat stress on growing and doe rabbits in Egypt. World Rabbit Sci., 3: 107.

Abdel-Samee, A.M. (1997). Adaptability of growing Bedouin X Albino goats to hot climate in Egypt. Intern. Conf. on Anim., Poultry, Rabbit Prod. And Health. Zagazig Univ. 2-4 September, Cairo, Egypt. PP. 367.

Abdel-Samee, A.M. (1998). Improving productivity of heat-stressed farm animals using different techniques.

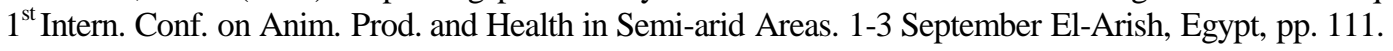

Abou-Raya, A.K. (1967). Animal and Poultry Nutrition. Dar-El-Maarif, Cairo, (Arabic Textbook).

Abu- El-Hamd, M. A. M. (2000). Effect of ascorbic acid as an additive on growth and physiological parameters of Frisian calves. M. Sc. Thesis, Fac. of Agric., Tanta Univ., Egypt.

Abu El-Hamd, M.A.; N. Ewada and Noura B.A. Bayoumy (2012). Effect of protected fat on productive and reproductive performance of friesian lactating cows during postpartum period. Egyptian J. Anim. Prod., (49):65-72.

Abu El-Hamd, M.A.; Y.M. El-Diahy, M.M. El-Maghraby and M.A. Elshora (2015). Effect of flaxseed oil on digestibility, blood parameters, immuno-response and productive performance of suckling Friesian calves.

Ambrose, D.; J.P. Kastelic; R. Corbett; P.A. Pitney; H.V. Petit; Small and P. Zalkovic (2006). Lower pregnancy losses in lactating dairy cows fed a diet enriched in alphalinolenic acid. J. Dairy Sci., 89: 3066-3074.

Andrew, S.M; H.F. Tyrrell; C.K. Reynolds and R.A Erdmen (1991). Net energy for lactation of calcium salts of long- chain fatty acids for cows fed silage- based diets. J. Dairy Sci.,74:2588.

Attebery, J.T. and H.N. Johnson (1969). Effect of environmental temperature, controlled feeding and fasting on rumen motility. J. Anim. Sci. 29: 734-737. 


\section{El-Diahy et al.}

Ballou, M.A. (2012). Immune responses of Holstein and Jersey calves during the pre-weaning and immediate post weaned periods when fed varying planes of milk replacer. J. Dairy Sci., 95:73197330.

Beede, D.K., and R.J. Collier. (1986). Potential nutritional strategies for intensively managed cattle during thermal-stress. J. Anim. Sci. 62:543-554.

Bendary, M.M.; I.A. Abou-Selim; M.R.M. Mostafa; A.M. Mahmoud and A.E.M. Khinizy (1994). Performance of fattening buffalo calves fed different levels of fat for two different period. Egypt J. Anim. Prod., 31 :613-626.

Bianchi, A.E.; V.P. Macedo; R.T. France; S.T. Lopes; L.M. Stefani; A. Volpato; L. Lima; D. Paiano; G. Machudo and S. Dasilva (2014). Effect of adding palm oil to the diet of dairy sheep on milk production and composition, function of liver and kidney, and the concentration of cholesterol, triglycerides and progesterone in blood serum. Small Ruminants Res.,117:78-83.

Chen, G. and J.B. Russell (1989). More monensin-sensitive, ammonia producing bacteria from the rumen. Applied and Environmental Microbiology, 55:1052-1057.

Chouinard, P.Y.; V. Girard and G.J. Brisson (1998). Fatty acid profile and physical properties of milk fat from cows fed calcium salts of fatty acids with varying unsaturation. J. Dairy Sci., 81:471-481.

Conners, W.E. (2000). Importance of n-3 fatty acids in health and disease. Am. J. Clin. Nutr., 71: 171175.

Conway, E. J. (1978). Microdiffusion analysis and volumetric error. 4th Ed. The McMillian Co., N.Y.

DeClercq, D.R. (2006). Quality of western Canadian flaxseed (2006). Canadian Grain Commission. Www.grainscanada.gc.ca

Drouillard, J.S.; E.J. Good; C.M. Gordon; T.J. Kessen; M.J. Sulpizio,; S.P. Montgomery and J.J. Sindt (2002). Flaxseed and flaxseed products for cattle: Effects on health, growth performance, carcass quality and sensory attributes. Proc. 59th Flax Institute, March 21-23, 2002, Fargo, N.D. pp 72-87.

Eadie, J.M.; P.N.Hobson and S.O. Monn.(1967). A note on some comparisons between the rumen content of barley fed steers and that of young calves also fed on high concentrate ration. Anim. Prod., 9:247-250.

El-Diahy, Y.M. (2004). Effect of fat supplementation on productive and reproductive performance in lactating Frisian cows. Msc Fac. of Agri. kafr El-Sheikh, Tanta Univ.

Fawzy, S.A. and Z.B.H. Rabie (1996). Effect of solar radiation on body reactions and semen characteristics of young Friesian bulls. Annals of Agric. Scie., Fac. of Agric., Moshtohor, Zagazig Univ. Egypt, 34: 569.

Fawzy, S.A.; M.H. El-Nenaey and A.E.B. Zeidan (1998). Effect of heat stress and its alleviation using water spray on growth and physiological functions of Friesian calves. $1^{\text {st }}$ Intern. Conf. on Anim. Prod. and Health in Semi-arid Areas, Sues Canal Univ. 1-3 September El-Arish, Egypt, pp. 243.

Fortes, C.; N. Agabiti; V. Fano; R. Pacifici; F. Forastiere; F. Virgili; P. Zuccaro; C.A. Perruci and S. Ebrahim (1997). Zinc supplementation and plasma lipid peroxides in an elderly population. European J. Clinical Nutrition 51, 97-101.

Frei, R; R.P Lauener; R. Crameri and L. OMahony (2012). Microbiota and dietary interactions - an update to the hygiene hypothesis? Allergy, 67: 451-461.

Fuquay, J. W. (1981). Heat stress as it affects animal production. J. Anim. Sci., 52: 164-174.

Getachew, G.; E.J. DePeters, P.H. Robinson and S.J. Taylor (2001). In vitro rumen fermentation and gas production: influence of yellow grease, tallow, corn oil and their potassium soaps. Anim. Feed Sci. Technol., $93: 1-15$.

Gonzalo, C.; J.A. Baro; J.A. Carriedo and F. San Primitivo (1993). Use of the Fossomatic method to determine somatic cell counts in sheep milk. J. Dairy Sci., 76:115-119.

Gornall, A.G.; G.J. Bardawill; G.J. and M.M. Daved, (1949). J. Biol. Chem. 177: 751. C. F. Hartmann and Lascelles

Grummer, R.R. (1995). Impact of changes in organic nutrient metabolism on feeding the transition dairy cow. J. Anim. Sci., 73:2820-2833. 
Holter, J. B.; J. W. West and M. L. McGilliard (1997). Predicting ad libitum dry matter intake and yield of Holstein cows. J. Dairy Sci., 80: 2188-2199.

Igono, M.O;; G. Bjotvedt and H.T. Sanford-Crane (1992). Environmental profile and critical temperature effects on milk production of Holstein cows in desert climate. Int. J. Biometeorol, 36(2): 77-87.

Ingraham, R.H.; R.W. Stanley and W.C. Wagner (1979). Seasonal effects of tropical climate on shaded and non shaded cows as measured by rectal temperature, adrenal cortex hormones, thyroid hormone, and milk production. Am. J. Vet. Res., 40:1792-1797.

Jalc, D.; A. Potkanski; M. Szumacher-Strabel; J. Kowalczyk and A. Cieslak (2006). The effect of a high concentrate diet and different fat sources on rumen fermentation in vitro. In: J. Anim. and Feed Sci., 15: $137-140$.

Jalc, D.; M. Certik; K. Kundrikova and P. Namestkova (2007). Effect of unsaturated C-18 fatty acids (oleic, linoleic and alpha-linolenic acid) on ruminal fermentation and production of fatty acid isomers in an artificial rumen. Veterinarni Medicina, 52: 87-94.

Jenkins, T.C. (1993). Lipid metabolism in the rumen. J. Dairy Sci., 76: 3851-3863.

Khattab, H.M.; A.Z. El-Basiony; S.M. Hamdy and A.A. Marwan (2011). Immune response and productive performance of dairy buffaloes and their offspring supplemented with black seed oil. Iranian J. Applied Anim. Sci., 1(4): 227-234.

Kobeisy, M.A. (1994). Effect of exposure to solar radiation on some physiological and hematological parameters in suckling Jersey calves fed ascorbic acid. Vet. Med. J. Giza, 42: 285-291.

Lee, J.R.; S.Y. Ku; B.C. Jee; C.S. Such and S.H. Kim (2008). Pregnancy outcomes of different methods for multifetal pregnancy reduction: a comparative study. J. Korean. Med .Sci., 23 : 111.

Lopes, N.; A.B. Scarpa; B.I. Cappellozza; R.F. Cooke and J.L.M. Vasconcelos (2009). Effects of rumenprotected polyunsaturated fatty acid supplementation on reproductive performance of Bos indicus beef cows. J. Anim. Sci., (87)12: 3935-3943.

Maddock, T.D.; M.L. Bauer; K. Koch; V.L. Anderson; R.J. Maddock and G.P. Lardy (2004). The effect of processing flax in beef feedlot rations on performance, carcass characteristics and trained sensory panel ratings. Proc. $60^{\text {th }}$ Flax Institute, March 17-19, 2004, Fargo, N.D. pp 118-123.

Mallonée, P.G.; D.K, Beede; R.J, Collier. and, C.J, Wilcox. (1985). Production and physiological responses of dairy cow to varying dietary potassium during heat stress. J. Dairy Sci., 68: 1479-1487.

Marai, I.F.M.; A.H. Daader; A.M. Abdel-Samee and H. Ibrahim (1997). Lactating Friesian and Holstein cows as affected by heat stress and combination of amelioration techniques under Egyptian conditions. Intern. Conf. on Anim., Poultry, Rabbit Prod. and Health. Zagazig Univ. 2-4 September, Cairo, Egypt. PP. 179.

Martin, C.; J. Rouel; J.P. Jouany; M. Doreau and Y. Chilliard (2008). Methane output and diet digestibility in response to feeding dairy cows crude linseed, extruded linseed, or linseed oil. J. Anim. Sci., 86: 2642-2650.

Moallem, U. (2009). The effects of extruded flaxseed supplementation to high-yielding dairy cows on milk production and milk fatty acid composition. Anim. Feed. Sci. Technol., 152, 232-242.

Mohsen, M.K.; M.I. BassIounI; H.M.a. Gaafar; M.H. el-shafIey and Heba A.A. El-Sanafawy (2011). Effect of whole sunflower seeds supplementation on performance of zaraibi goats. Slovak J. Anim. Sci., 44 (4): 154-161.

Mostafa, M.R.M.; M.M. Bendary; A.M. Mahmoud; I.A. Abou-Selim and W.H. Abdel-Malik (1995). Productive performance of lactating buffaloes fed rations containing different levels of vegetable fat. Proc. $5^{\text {th }}$ Sci. Conf. Anim. Nutr., Vol. 7:103-113, Ismolia, Egypt.

Mustafa, A.F.; J.J. McKinnon; D.A. Christensen and T. He (2002). Effects of micronization of flaxseed on nutrient disappearance in the gastrointestinal tract of steers. Anim. Feed Sci. Technol., 95: 123132.

Nash, D.M.; R.M.G. Hamilton and H.W. Hulan (1995). The effect of dietary herring meal on the omega-3 fatty acid content of plasma and egg yolk lipids of laying hens. Can. J. Anim. Sci.,75: 247-253.

National Research Council (NRC), (2001). Pages in nutrient requirements of dairy cattle. $7^{\text {th }}$ rev. ed. Natl. Acad. Sci., Washington DC. 


\section{El-Diahy et al.}

Ndiweni, N. and J.M. Finch (1995). Effect of in vitro supplementation of bovine mammary gland macrophages and peripheral blood lymphocytes with $\alpha$-tocopherol and sodium selenite: Implications for udder defenses. Vet. Immuonl. Immunopathol., 47:111-121.

Overton, T.R. and M.R. Waldron (2004). Nutritional management of transition dairy cows: Strategies to optimize metabolic health. J. Dairy Sci., 87: 105-119.

Petit, H.V. (2003). Digestion, milk production, milk composition and blood composition of dairy cows fed formaldehyde treated flaxseed or sunflower seed. J. Dairy Sci., 86: 2637-2646.

Petit, H.V.; C. Germiquet and D. Lebel (2004). Effect of feeding whole, unprocessed sunflower seeds and flaxseeds on milk production, milk composition and prostaglandin secretion in dairy cows. J. Dairy Sci., 87:3889-3898.

Petit, H.V.; R.J. Dewhurst; J.G. Proulx; M. Khalid; W.Haresign and H. Twagiramungu (2001). Milk production, milk composition and reproductive function of dairy cows fed different fats. Can. J. Anim. Sci., 81: 263-271.

Ravagnolo, O.; I. Misztal and G. Hoogenboom (2000). Genetic compnent of heat stress in dairy cattle, development of heat index function. J. Dairy Sci., 83:2120-2125.

Reist, M.; D. Erdin; D. Von Euw; K. Tschuemperlin; H. Leunberger; H. Chilliard; M. Hammon; C. Morel; C. Philopona; Y. Zbinder; N. Kuenzi and J.W. Blum (2002). Estimation of energy balance at the individual and herd level using blood and milk traits in high-yielding dairy cows. J. Dairy Sci., 85: 3314-3327.

Salem, I.A.; S.A. Mokhtar and M.A. Kobeisy (1984). Thermal and respiratory responses of dry non-pregnant Frisian cows to seasonal and diurnal climatic conciliations in upper Egypt. Reprinted From Assiut J. of Agric. Sci., 15: (2), 1084.

Santos, J.E.P.; T.R.Bilby; W.W. Thatcher; C.R. Staples and F.T. Silvestre (2008). Long chain fatty acids of diet as factors influencing reproduction in cattle. Reprod Domestic Anim., (43)2: 23-30.

SAS. (2004). SAS/STAT User's Guide: Volumes 1-7. SAS Institute Inc., Cary, North Carolina.

Simopoulos, A. P. (1996). Omega-3-fatty acids and public health. Proc. Flax Council of Canada Conf. Flax, the Next Decade. 1996 Dec. 3-4. Winnipeg, MB. pp. 5-28.

Staples, C.R. and W.W. Thatcher (2005). Effects of fatty acids on reproduction of dairy cows. In: Garnsworthy PC, Wiseman, J. (Eds.), Recent Advances in Animal Nutrition. Nottingham University Press, Nottingham, UK, 229-256 p.

Strusinska, D;, D, Minakowski;, B, Pysera and, J, Kaliniewicz. (2006). Effects of fat-protein supplementation of diets for cows in early lactation on milk yield and composition. Czech J. Anim. Sci., 51, 196-204.

Toral, P.G.; A. Belenguer; P. Frutos and G. Hervas (2009). Effect of the supplementation of a highconcentrate diet with sunflower and fish oils on ruminal fermentation in sheep. Small Ruminant Research, 81:119-125.

Van Keulen, J. and B.A. Young (1977). Evaluation of acid insoluble ash as a digestibility studies. J. Anim. Sci., 44: 282.

Vargas, J.E.; S. Andres D.R. Yanez Ruiz and S. Lopez (2011). The effect of olive, sunflower or linseed oils on the fermentation pattern and methane production in the rumen simulating technique 1 Options Méditerranéennes: Serie A. Séminaires Méditerranéens, 99 :163- 168.

Veenhuizen, J.J; J.K. Drackley; M.J. Richard; T.P. Sanderson; L.D. Miller; and J.W. Joung (1991). Metabolic changes in blood and liver during development and early treetment of Expermental Fatty liver and ketosis in cows, J. Dairy Sci., 74: 4238-4253.

West, J.W. (2003). Effects of heat-stress on production in dairy cattle. J. Dairy Sci., 86:2131-2144.

Wichselarm, T.E. (1946). Method for determination of albumin in serum blood. Amer. J. Clin. Pathol ., 16:40.

Wonnacott, K.E.; W.Y. Kwong; J. Hughes; A.M. Salter; R.G. Lea; P.C. Garnsworthy and K.D. Sinclair (2010). Dietary omega-3 and -6 polyunsaturated fatty acids affect the composition and development of sheep granulosa cells, oocytes and embryos. Reprod., 139: 57-69. 
Wright, T.; B. McBride and B. Holub (1998). Docosahexaenoic acid-enriched milk. World Rev. Nutr. Diet., 83: 160-165.

Yousef, H. M.; A. A. Habeeb and H. El- Kousey (1997). Body weight gain and some philological changes in Friesian calves protected with wood or reinforced concrete sheep's during hot summer on Egypt. Egyptian J. Anim. Prod.

Zachut, M.; A. Arieli and U. Moallem (2011). Incorporation of dietary n-3 fatty acids into ovarian compartments in dairy cows and the effects on hormonal and behavioral patterns around estrus. Reprod., 141: 833-840.

تأثير أضافه زيت الكتان قبل و بعد الولادة على بعض المقاييس الفسيولوجية والأداء الإنتاجي في الأبقار الفريزيان

$$
\begin{aligned}
& \text { ياسر مبروك الديهى, محمل عوض أبو الحمد وبحمل احمد الثوره } \\
& \text { معطج بحوث الإنتاج الحيوانس , مركز البحوث الزرراعية , وزارة الزراعة , مصر. }
\end{aligned}
$$

تهدف هذه الدراسة إلى تقيبم أثثر إضافة زيت الكتان خلال الفترة ما قبل وبعد الو لادة على المأكول ومعاملات الهضانم ونشاط الكرش

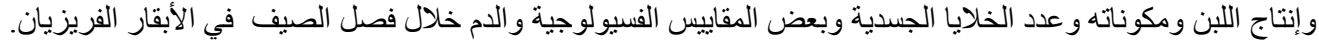

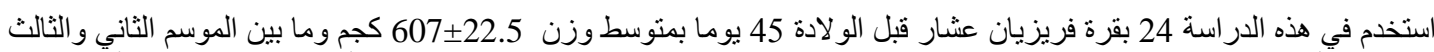

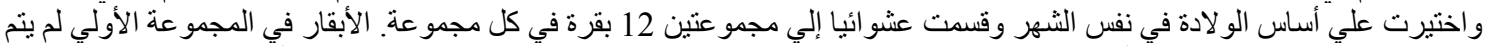

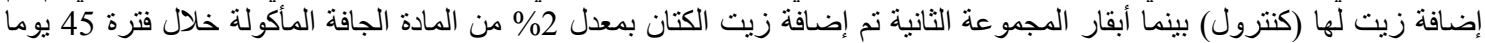

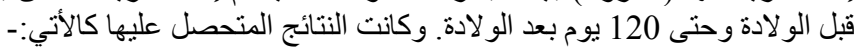

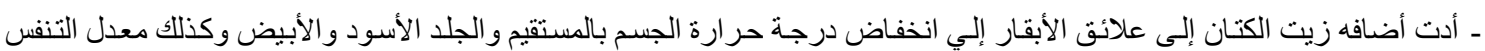

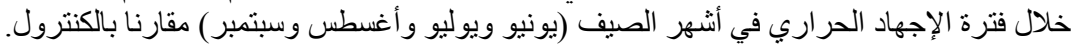

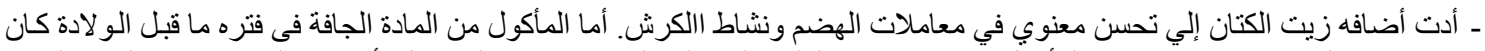

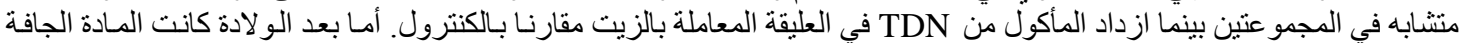

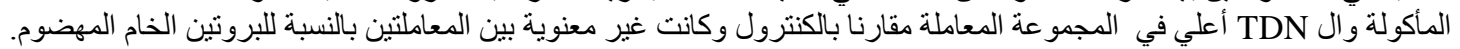

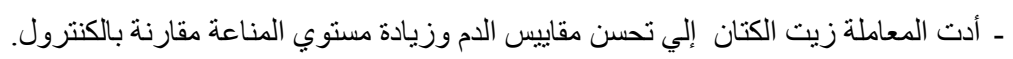

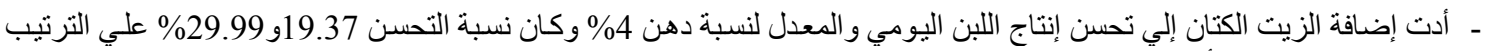

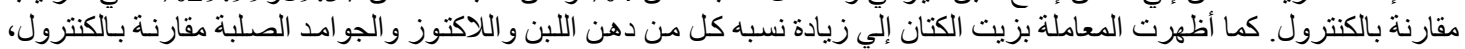
بينما باقي المكونات اللبن لم تتخير.

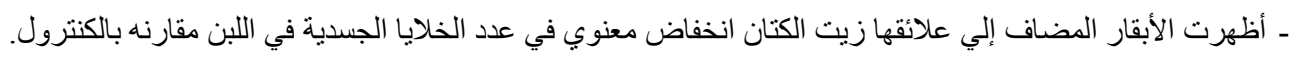
ـ كما أظهرت المعاملة بزيت الكتان إلي تحسن كفاءة الغذاء والكفاءة الاقتصادية.

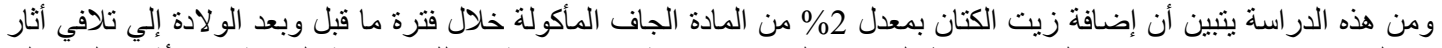

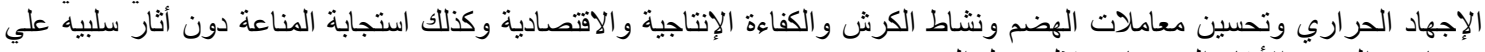
خصائص الدم في الأبقار الفريزيان خلال فصل الصيف. 